\title{
Neurosurgical strategies for Gilles de la Tourette's syndrome
}

\author{
Karim Mukhida ${ }^{1,2}$ \\ Matthew Bishop ${ }^{2}$ \\ Murray Hong ${ }^{2}$ \\ Ivar Mendez ${ }^{2}$ \\ 'Division of Neurosurgery, \\ University of Toronto, Toronto, \\ Ontario, Canada; ${ }^{2}$ Departments \\ of Anatomy and Neurobiology \\ and Surgery (Neurosurgery), \\ Dalhousie University, Halifax, \\ Nova Scotia, Canada
}

\begin{abstract}
Tourette's syndrome (TS) is a neurological disorder characterized by motor and vocal tics that typically begin in childhood and often are accompanied by psychiatric comorbidities. Symptoms of TS may be socially disabling and cause secondary medical complications. Pharmacological therapies remain the mainstay of symptom management. For the subset of patients in whom TS symptoms are medically recalcitrant and do not dissipate by adulthood, neurosurgery may offer an alternative treatment strategy. Greater understanding of the neuroanatomic and pathophysiologic basis of TS has facilitated the development of surgical procedures that aim to ameliorate TS symptoms by lesions or deep brain stimulation of cerebral structures. Herein, the rationale for the surgical management of TS is discussed and neurosurgical experiences since the 1960s are reviewed. The necessity for neurosurgical strategies to be performed with appropriate ethical considerations is highlighted.
\end{abstract}

Keywords: tourette's syndrome, neurosurgery, deep brain stimulation, thalamus

\section{Introduction Historical perspective}

In 1825, Jean-Marc Gaspard Itard, the Chief Physician at the National Institute for Deaf Mutes in Paris, provided careful clinical observations of stereotypic movements and vocalizations in the 26-year-old Marquise de Dampierre:

[she] began to have convulsive contractions in her hand and arm muscles, which manifested themselves especially at the moments in which this [woman as a] child tried to write as she spread her hand over the characters that she traced. After this deviation, her hand movements returned to normal once more and were subject to her will until another jolt interrupted the operation of her hand once more...soon it became certain that these movements were involuntary and convulsive, as the muscles of the shoulders, the neck and the face participated in them. The malady continued to progress, spasms were propagated in the organs of the voice and of the speech, and this young woman uttered bizarre cries and words which made no sense (Itard 1825).

The socially disabling effects of the disorder were also clear to Itard:

Among the continuous and disordered movements which lead to these morbid contractions, those imparted by the organs of voice and speech are the only ones deserving all our attention as presenting the more rare phenomenon as well as constituting the most disagreeable inconvenience, one which prevents the person from attaining all the kindnesses society offers; because the disorder that she bears is proportional to the pleasure of which it deprives her...the more others seem revolted by her uncivilized statements, the more she is tormented by the fear of uttering them (Itard 1825).

Although George Beard (1880-1881) later described an additional fifty patients with motor tics and echolalia, the disorder was eponymously named by Jean-Martin Charcot after his student Georges Gilles de la Tourette, who had written a two-part manuscript 
in 1885 describing nine affected patients, including the Marquise (Gilles de la Tourette 1885).

\section{Clinical features of Tourette's syndrome}

The clinical features of Tourette's syndrome (TS) as described by those original reports remain the basis for current diagnostic criteria. More specifically, both the Tourette Syndrome Classification Study Group and the Diagnostic and Statistical Manual of Mental Disorders (DSM-IV) (The Tourette Syndrome Classification Study Group 1993; Müller-Vahl 2002) currently require the presence of multiple motor and vocal tics (stereotyped, purposeless, and involuntary movements or sounds) daily or intermittently over the course of over one year, and with onset in childhood (prior to eighteen years of age for the DSM-IV). An additional essential diagnostic criterion is tic variability; that is, their severity, frequency, and affected anatomic location must vary over the course of the disorder (The Tourette Syndrome Classification Study Group 1993).

Categorization of TS into subtypes according to the patient's symptoms has been proposed (Shapiro et al 1988; Robertson et al 1990; Jankovic 2001). Simple TS is characterized by the predominance of motor and vocal tics, whereas more complex subtypes feature coprolalia, copropraxia, echolalia, echopraxia, palilalia, and/or palipraxia (Robertson et al 1990; Jankovic 2001). Patients with TS may also commonly exhibit other behavioral symptoms (Gilbert 2006), such as attention deficit-hyperactivity disorder (Robertson 2000), obsessive compulsive disorder (Frankel et al 1986; Como 1995), self-injurious behaviors (Robertson et al 1989; Kurlan et al 1990; Leckman et al 1993; Houeto et al 2005; Anandan et al 2004; Ackermans et al 2007), and/or anxiety disorders (Robertson 2000).

Treatment of TS symptoms is pursued if the symptoms adversely affect quality of life or cause medical complications (Singer 2001). Patients who exhibit mild symptoms may require only psychobehavioral therapies and the support of family, teachers, and TS support groups (Kurlan 1997; Müller-Vahl 2002; Visser-Vanderwalle 2007). Some patients may be able to avoid the use of pharmacological therapies since TS is unique as a hyperkinetic movement disorder in that patients describe the ability to suppress their tics (Demirkiran and Jankovic 1995), at least in part. Moreover, although patients typically demonstrate a chronic disease course, symptom remission may occur spontaneously in up to $40 \%$ of patients by late adolescence and an additional $30 \%$ of patients may experience later symptom improvement (Bruun and Budman 1992; Leckman et al 1998; Babel et al 2001).
Pharmacological therapies may be beneficial for patients whose tics do not respond sufficiently to conservative treatments or are functionally incapacitating (Gilbert 2006). The association of tics with medical or psychiatric conditions may necessitate more aggressive tic management. For example, TS has been associated with self-injurious behaviors requiring urgent medical attention (Robertson et al 1989; Kurlan et al 1990; Leckman et al 1993; Houeto et al 2005; Anandan et al 2004; Ackermans et al 2007), such as corneal and orbital injuries (Robertson et al 1990) and stab wound- inflicted injuries (Anandan et al 2004), or tic-induced medical complications, such as cervical myelopathy (Krauss and Jankovic 1996), limb fractures, and retinal detachments (Flaherty et al 2005). The variety of medications used to manage TS has included dopaminergic antagonists, benzodiazepines, calcium channel antagonists, and atypical neuroleptics (Kurlan 1997; Robertson and Stern 2000; Jiménez-Jiménez and García-Ruiz 2001; Müller-Vahl 2002). Botulinum toxin injections have been used to treat painful dystonic tics (Jankovic 1994). Medical therapies may be particularly useful even during the waning phase of tics in early adolescence since tics have been reported to worsen at that time before they may ultimately resolve (Leckman et al 1998). However, medical therapies may cause detrimental and intolerable side effects (Leckman 2002; Flaherty et al 2005) and, for a subset of patients with TS, are ineffective (Müller-Vahl 2002; Visser-Vandewalle 2007). As Kopell and colleagues (2003) note, the development of additional treatment strategies for this subset of patients is particularly important given that the endpoint for unsatisfactorily managed neuropsychiatric disease is "dismal".

\section{Pathophysiology of Tourette's syndrome} Anatomical studies

The development of surgical strategies for medically recalcitrant TS was enabled by efforts to localize an anatomical source of the symptoms. Psychodynamic theories prior to the 1970s sought to explain tics as resulting from suppressed aggression and "impaired functioning of the 'motility controlling function of the ego" " (Mahler and Luke 1946; Flinn et al 1983). Autopsy findings from patients with TS that demonstrated no specific anatomical pathologies or only subtle changes in the striatum seemed to support conceptions that tics had a psychogenic origin (DeWulf and van Bogaert 1941; Balthasar 1957). The search for an anatomical basis for TS using autopsy material is thought to be problematic, however, both because few post-mortem brains have been studied and most of those available have 
come from patients with long-standing disease and treatment that might confound the histological analyses (Mink et al 2001; Frey et al 2006). Nevertheless, more recent studies have found abnormalities particularly in the basal ganglia and frontal cortex. For example, studies have reported decreased levels of dynorphin-like immunoreactivity in the striatum and globus pallidus (Haber et al 1986; Haber and Wolfer 1992), decreased subcortical levels of serotonin (Anderson et al 1992), increased numbers of neurons expressing parvalbumin in the globus pallidus pars internus (GPi) and decreased numbers of neurons expressing parvalbumin in the caudate nucleus and globus pallidus pars externus (GPe) (Kalanithi et al 2005). Interestingly, Itard had speculated that the symptoms of TS had a cerebral origin in his 1825 case report:

What is the nature of these strange convulsions, or to pose the question in a clearer manner, the seat of the irritation which provokes them? Considering that the muscles which move against the will belong to different motor apparatuses which are not managed by the same nerves, this irritation is not caused by any of them but at their common centre which is the brain.

\section{Neuroimaging studies}

Modern imaging studies lend further evidence for a neuroanatomic basis of TS. Asymmetric striatal volumes have been observed in magnetic resonance images (MRI) of patients with TS, with smaller striatal volumes suggesting abnormalities in striatal development or the loss of GABAergic interneurons that are thought to play a role in gating sensory information (Peterson et al 1993; Singer et al 1993). Abnormally smaller caudate volumes are thought to be predictive of the development of more severe tics in early adulthood (Bloch et al 2005) and have been associated with more severe symptoms in twin studies (Hyde et al 1995). Abnormalities of volume also have been observed in the lenticular nuclei (Peterson et al 1993; Singer et al 1993). These findings are inconsistent, however, since other studies have found no significant differences in basal ganglia nuclei volumes compared to those of normal control patients (Moriarty et al 1997; Zimmerman et al 2000), or have found increased caudate volumes in children with TS (Denkla et al 1991). Functional MRI has revealed activity in the neocortex, striatum, thalamus, parietal operculum, supplementary motor area, insular cortex, and cerebellum in association with tic generation (Peterson 2001; Bohlhalter et al 2006; Lerner et al 2007), while increased activity in the caudate and frontal and temporal cortices and decreased activity in the ventral GP, putamen and thalamus have been observed during tic suppression (Peterson 2001).
Increased activation of the substantia nigra, ventral tegmental area, and basal ganglia structures of the direct pathway has also been associated with increased tic severity in nonmedicated children with TS (Baym et al 2008). Positron emission tomography (PET) studies using ${ }^{18} \mathrm{~F}$-fluorodeoxyglucose in patients with TS demonstrate increased metabolic activity in the premotor and supplementary cortices and midbrain and concomitant decreased activity in the caudate and thalamus (Stoetter et al 1992; Eidelberg et al 1997) while in those studies using ${ }^{15} \mathrm{O}$-water found increased activity in cerebral regions associated with sensorimotor, language, executive and paralimbic functions, which was temporally related to both the expression of motor and phonic tics and their premonitory urges (Stern et al 2000). Finally, consistent with PET findings of decreased glucose utilization, single photon emission tomography (SPECT) has revealed decreased regional blood perfusion of the basal ganglia, thalamus, and frontal and temporal cortices in TS (Peterson et al 1993).

Anatomic localization of TS symptom generation to the basal ganglia is consistent with current understanding of basal ganglia physiology. In a general sense, disordered cortico-striato-pallido-thalamo-cortical circuitry is thought to be etiologically-related to TS, although the specific nuclei and circuits responsible for the various symptoms remain a matter of continued investigation (Müller-Vahl 2002; Mink et al 2006). It has been suggested, for example, that simple motor tics could be due to abnormal activation of the motor cortex via thalamocortical pathways while involvement of premotor, supplementary motor, and cingulate cortices may be related to more complex motor tics (Stern et al 2000; Mink et al 2001). Inappropriate activity in Broca's area, the frontal operculum, and the caudate nucleus could elicit vocal tics (Stern et al 2000; Mink et al 2001). Abnormal activation of the orbitofrontal region, which has been observed in obsessive compulsive disorder, may underlie the compulsions and urges that patients with TS experience (Stern et al 2000; Mink et al 2001). Alternatively, tics in TS may be due to abnormal activity within subsets of neurons within the caudate and putamen (Graybiel et al 1994; Mink et al 2001); indeed, microstimulation of discrete areas of the putamen in monkeys induces stereotypic movements akin to tics (Alexander et al 1985).

\section{Neurotransmitter studies}

Given the diversity of nuclei and circuits that may be involved in TS pathogenesis, the variety of neurotransmitter systems that are also implicated is not surprising (Jankovic 2001). In the frontal subcortical circuits alone, abnormalities in 
glutamate, dopamine, serotonin, GABA, acetylcholine, noradrenaline, opioid, and cannabinoid receptors are thought to be involved (Lavenstein et al 2003). The serotonergic system has been studied in particular: patients with TS have been found to have decreased levels of serotonin and its metabolite 5-hydroxyindoleacetic acid in their serum (Comings 1990) and cerebrospinal fluid (Butler et al 1979), respectively, and post-mortem studies have found decreased serotonin levels in the brain stem (Swerdlow and Young 2001). This latter finding is particularly relevant since serotonergic projections from the medial raphe nucleus are known to project to regions implicated in tic generation, such as the prefrontal cortex, substantia nigra pars compacta, ventral tegmental area, striatum, and nucleus accumbens (Alex et al 2005; Pehek et al 2006). These target structures are components of the dopaminergic system and, thus, it has been hypothesized that it is not serotonergic dysfunction, per se, that induces tics, but rather its effects on the dopaminergic system (Harris et al 2006). Serotonin influences dopaminergic release via a number of receptors, including serotonin heteroreceptors and inhibitory and stimulatory somatodendritic receptors, and is involved in dopamine reuptake (Sershen et al 2000; Alex et al 2005; Pehek et al 2006; Carta et al 2007).

Indeed, the most widely purported hypothesis to explain the etiology of TS concerns dopaminergic circuitry dysfunction. The ability of dopaminergic antagonists to suppress

\section{Normal}

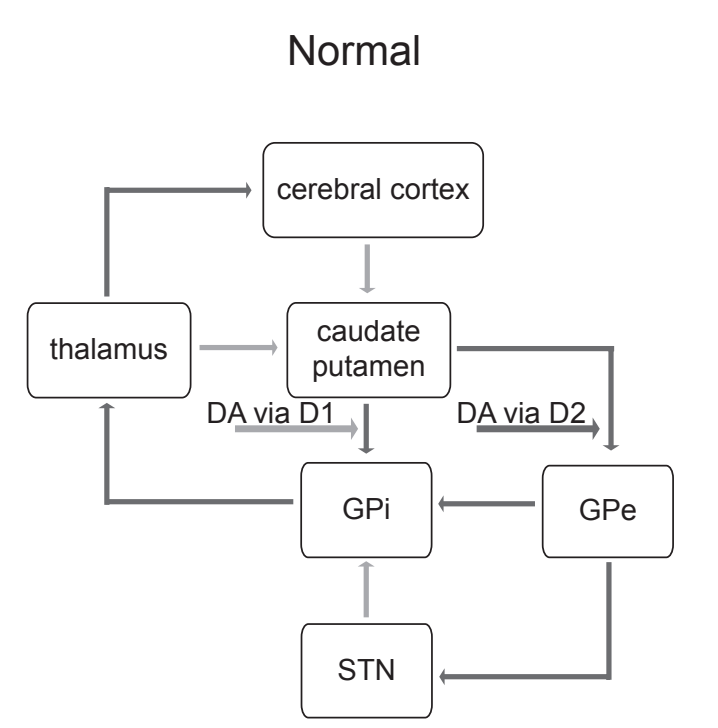

tics suggests that the dopaminergic system is hyperactive in TS (Jankovic 2001). The direct dopaminergic basal ganglia pathway is thus facilitated, and the indirect pathway inhibited, which results in thalamocortical over-activity (VisserVandewalle 2007; Figure 1). Dopaminergic hyperactivity could arise due to alterations in dopamine release (Snyder et al 1970; Singer et al 1982; Harris et al 2006). Imaging studies In TS suggest an "overactive DAT [dopamine transporter] system" (Harris et al 2006): for example, SPECT has demonstrated increased dopamine transporter binding in the striatum in patients with TS (Cheon et al 2004; Serra-Mestres et al 2004), suggesting an elevated density of presynaptic dopamine terminals and postsynaptic D2 dopamine receptors, particularly in the ventral striatum (Wong et al 1989; Ernst et al 1999; Wolf et al 1996; Albin et al 2003). In further study of $\mathrm{D} 2$ receptors using ${ }^{11} \mathrm{C}$ raclopride $\mathrm{PET}$, amphetamine challenge caused a $21 \%$ increase in intrasynaptic dopamine levels that was not observed in control patients (Singer et al 2002). Although D2 receptor density has correlated with TS symptom intensity in monozygotic twins (Wolf et al 1996), this has not been consistently observed (Wong et al 1997). The net result of increased DAT density is decreased tonic extracellular levels of dopamine, increased dopamine levels in the axon terminal, and dopamine receptor supersensitivity (reviewed in Harris et al 2006). Alternatively, TS may result not from abnormalities of dopaminergic transmission but from changes in the resting

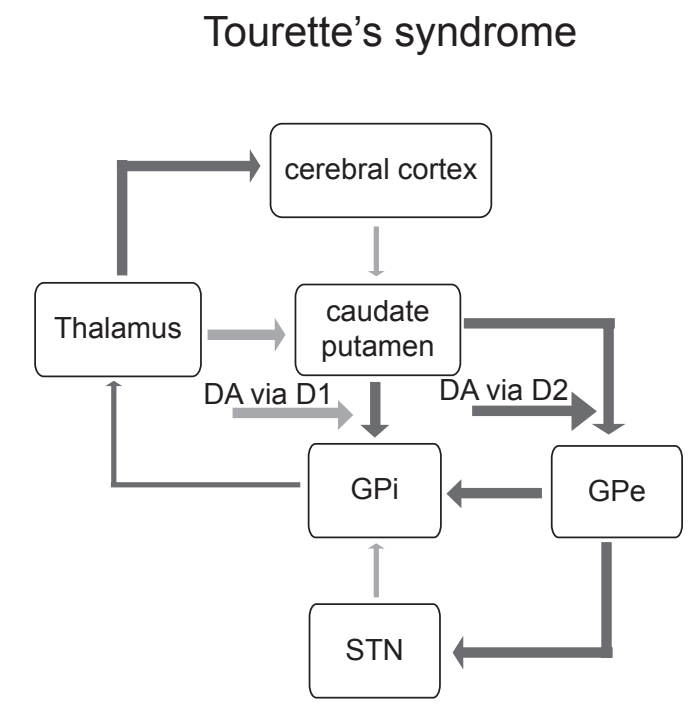

Figure I Schematic representation of basal ganglia circuitry (modified from Visser-Vandewalle et al 1997), with excitatory (glutamatergic) projections $\longrightarrow$ and inhibitory (GABAergic) projections $\longrightarrow$. Normally, dopamine, acting via DI dopamine receptors, has an excitatory influence on striatal projections to the GPi and, acting via D2 dopamine receptors, an inhibitory influence on striatal projections to the GPe, maintaining a balance between the activities of the direct and indirect basal ganglia pathways. According to the dopaminergic hypothesis of TS pathophysiology, dopaminergic hyperactivity causes increased activity in the direct pathway (indicated by the heavier weighted lines) and decreased activity in the indirect pathway, which serves to enhance thalamocortical activity. In TS, the thalamus, caudate-putamen, and GPe become pathologically hyperactive, and the GPi and STN become pathologically hypoactive.

Abbreviations: GPi, globus pallidus pars internus; GPe, globus pallidus pars externus; STN, subthalamic nucleus; DA, dopamine. 
membrane potentials of striatal neurons whose response to dopamine is consequently affected (Mink et al 2001).

\section{Animal studies}

Animal models have been developed to better understand the pathophysiologic basis of TS (Swerdlow and Sutherland 2005, 2006). Normally, a prestimulus can prevent a startle response elicited by a stimulus, but this has been found to be deficient in TS (Castellanos et al 1996; Freudenberg et al 2007). This is thought to be due to deficient "gating" of sensorimotor information and has been modelled in rodents, pigs, and nonhuman primates (Swerdlow et al 2001; Swerdlow and Sutherland 2005; Freudenberg et al 2007; Hadamitzky et al 2007). In order to model the hyperactive basal ganglia and limbic circuitry thought to underlie TS, transgenic mice have been developed that have tonically hyperactive cortical and limbic circuits (Campbell et al 2000; McGrath et al 2000;
Nordstrom and Burton 2002; Swerdlow and Sutherland 2005, 2007). These rodents display tics as well as compulsive behaviors (Campbell et al 2000; McGrath et al 2000; Nordstrom and Burton 2002; Swerdlow and Sutherland 2005, 2007). Microinjection of the $\mathrm{GABA}_{\mathrm{A}}$ antagonist bicuculline in the limbic area of the GPe has also been shown to induce complex tics and compulsions in African green monkeys and may therefore provide an additional primate model of TS (Grabli et al 2004). In addition to enhancing understanding of abnormal TS neural circuitries, animal models could be used to test surgical therapies before they are introduced to the clinical setting.

\section{Neurosurgical lesions Frontal lobe disconnection}

Surgical disruption of basal ganglia circuits began to be employed for the treatment of TS in 1955 (Stevens 1964; Figure 2, Table 1). The earliest studies focused on

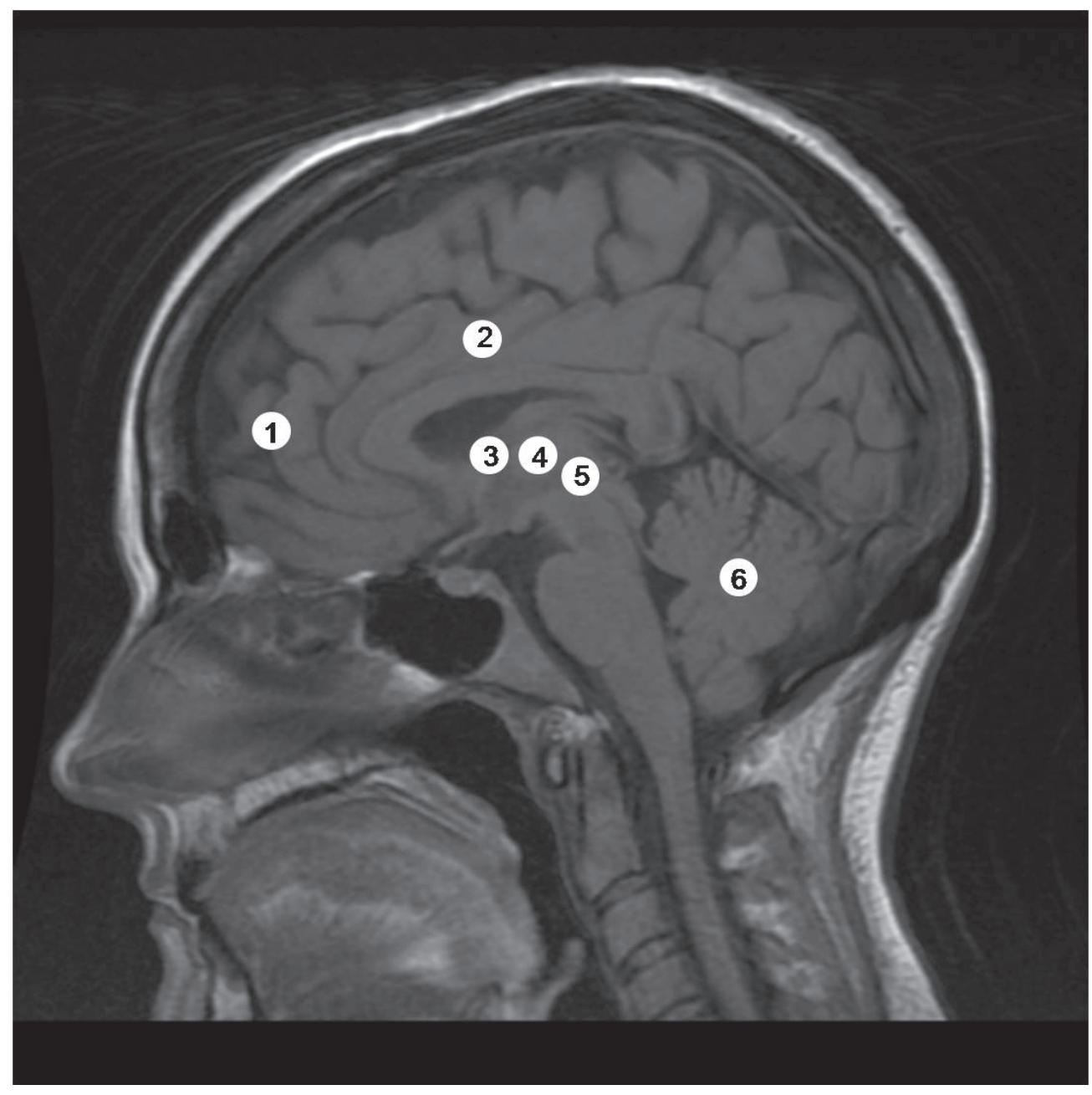

Figure 2 Sagittal magnetic resonance image demonstrating the sites of lesions for TS.

Notes: I, frontal leucotomy; 2, cingulotomy; 3, zona incerta lesion; 4, thalamotomy; 5, hypothalamotomy; and 6, dentatotomy. 
Table I Clinical studies of neurosurgical lesions for Tourette's syndrome

\begin{tabular}{|c|c|c|c|c|c|c|}
\hline Study effects & $\begin{array}{l}\text { Study } \\
\text { design }\end{array}$ & $\mathbf{n}$ & $\begin{array}{l}\text { Comorbid } \\
\text { diagnoses }\end{array}$ & Lesion & Outcomes & Adverse \\
\hline Baker 1962 & $\begin{array}{l}\text { Case } \\
\text { report }\end{array}$ & I & anxiety & Bimedial frontal leucuotomy & $\begin{array}{l}\text { - Follow-up: I year } \\
\text { - tics and panic attacks } \\
\text { "markedly reduced" }\end{array}$ & - frontal lobe abscess \\
\hline Stevens 1964 & $\begin{array}{l}\text { Case } \\
\text { report }\end{array}$ & 1 & - & Transorbital lobotomy & $\begin{array}{l}\text { - Follow-up: } 9 \text { years } \\
\text { - significant decrease in } \\
\text { frequency, duration, and } \\
\text { amplitude of tics }\end{array}$ & - obesity \\
\hline $\begin{array}{l}\text { Hassler and } \\
\text { Dieckmann } 1970\end{array}$ & $\begin{array}{l}\text { Case } \\
\text { series }\end{array}$ & 3 & OCD & $\begin{array}{l}\text { Thalamotomy (bilaterally; } \\
\text { targeted rostral intralaminar and } \\
\text { medial nuclei) }\end{array}$ & $\begin{array}{l}\text { - Follow-up: time not } \\
\text { specified } \\
\text { - Evaluation: techniques } \\
\text { not specified } \\
\text { - } 70 \%-100 \% \\
\text { improvement of } \\
\text { coprolalia and tics }\end{array}$ & - mood alterations \\
\hline Nádvorník et al 1972 & $\begin{array}{l}\text { Case } \\
\text { report }\end{array}$ & I & not indicated & Dentatotomy (bilateral) & $\begin{array}{l}\text { - Follow-up: time not } \\
\text { specified } \\
\text { - decrease in motor } \\
\text { tics and resolution of } \\
\text { vocal tics }\end{array}$ & - none reported \\
\hline de Divitiis et al 1977 & $\begin{array}{l}\text { Case } \\
\text { series }\end{array}$ & 3 & OCD & $\begin{array}{l}\text { Thalamotomy (unilateral, except } \\
\text { for I patient who also received a } \\
\text { contralateral thalamotomy) }\end{array}$ & $\begin{array}{l}\text { - Follow-up: } \\
\text { at least I year } \\
\text { (exact time not } \\
\text { specified) } \\
\text { - complete remission } \\
\text { of tics for > I year but } \\
\text { then recurrence of } \\
\text { symptoms } 2 \text { patients) } \\
\text { - no improvement of } \\
\text { tics (I patient) }\end{array}$ & $\begin{array}{l}\text { •"prolonged mental } \\
\text { confusion" (I patient) }\end{array}$ \\
\hline Kurlan et al 1988 & $\begin{array}{l}\text { Case } \\
\text { series }\end{array}$ & 2 & OCD & Cingulotomy & $\begin{array}{l}\text { - Follow-up: time not } \\
\text { specified } \\
\text { - transient } \\
\text { improvement of tics } \\
\text { - slight improvement of } \\
\text { ritualistic behavior }\end{array}$ & - none reported \\
\hline Kurlan et al 1990 & $\begin{array}{l}\text { Case } \\
\text { series }\end{array}$ & 2 & OCD & $\begin{array}{l}\text { Cingulotomy (bilateral anterior; } \\
\text { I patient had procedure } \\
\text { repeated } 8 \text { months after first) }\end{array}$ & $\begin{array}{l}\text { - Follow-up: up to } \\
2 \text { years } \\
\text { - Evaluation: clinical } \\
\text { rating scales not } \\
\text { utilized } \\
\text { - No effects on tics } \\
\text { or coprolalia }\end{array}$ & $\begin{array}{l}\text { - aseptic meningitis } \\
\text { for patient who } \\
\text { underwent two } \\
\text { procedures }\end{array}$ \\
\hline Robertson et al 1990 & $\begin{array}{l}\text { Case } \\
\text { report }\end{array}$ & I & SIB & Cingulotomy (bilateral) & - Follow-up: 2 years & - mild apathy \\
\hline $\begin{array}{l}\text { intellectual } \\
\text { impairment }\end{array}$ & & & & & - Evaluation: LOI, BDI & $\begin{array}{l}\text { - general intellectual } \\
\text { impairment }\end{array}$ \\
\hline $\begin{array}{l}\text { difficulties with orga- } \\
\text { nization concentration }\end{array}$ & & & & & $\cdot 75 \% \downarrow$ severity of tics & \\
\hline
\end{tabular}


Table I (Continued)

\begin{tabular}{|c|c|c|c|c|c|c|}
\hline Study effects & $\begin{array}{l}\text { Study } \\
\text { design }\end{array}$ & $\mathbf{n}$ & $\begin{array}{l}\text { Comorbid } \\
\text { diagnoses }\end{array}$ & Lesion & Outcomes & Adverse \\
\hline \multirow[t]{3}{*}{ Leckman et al 1993} & $\begin{array}{l}\text { Case } \\
\text { report }\end{array}$ & 1 & OCD & $\begin{array}{l}\text { Cingulotomy (bilateral } \\
\text { anterior) and infrathalamic lesion } \\
\text { (bilateral) }\end{array}$ & - Follow-up: I6 months & - sepsis \\
\hline & & & & $\begin{array}{l}\text { Left cingulated and infra-thalamic } \\
\text { lesions repeated I month later }\end{array}$ & $\begin{array}{l}\text { • Evaluation:YBOCS, } \\
\text { YGTSS }\end{array}$ & $\begin{array}{l}\text { - dysarthria, dysphagia, } \\
\text { dysphonia }\end{array}$ \\
\hline & & & & & $\begin{array}{l}\text { - improvement in tics } \\
\text { (YGTSS score } \downarrow \text { from } \\
22 \text { to I5) }\end{array}$ & $\begin{array}{l}\text { - severe handwriting } \\
\text { problems, } \\
\text { micrographia }\end{array}$ \\
\hline \multirow[t]{2}{*}{ Sawle et al 1993} & $\begin{array}{l}\text { Case } \\
\text { report }\end{array}$ & 1 & OCD, SIB & $\begin{array}{l}\text { Hypothalamus (anterior) and } \\
\text { cingulotomy (inferior) }\end{array}$ & - Follow-up: 21 months & - none reported \\
\hline & & & & & $\begin{array}{l}\text { - by } 19 \text { months } \\
\text { no clinical signs of } \\
\text { Tourette's syndrome }\end{array}$ & \\
\hline \multirow[t]{3}{*}{ Baer et al 1994} & $\begin{array}{l}\text { Case } \\
\text { report }\end{array}$ & 1 & OCD & $\begin{array}{l}\text { Cingulotomy (second } \\
\text { cingulotomy performed } \\
\text { I } 8 \text { months after the first) }\end{array}$ & $\begin{array}{l}\text { - Follow-up: I8 months } \\
\text { (first cingulotomy); } \\
\text { I } 3 \text { months (second } \\
\text { cingulotomy) }\end{array}$ & - none reported \\
\hline & & & & & $\begin{array}{l}\text { • Evaluation:YBOCS, } \\
\text { BDI, CGI scale }\end{array}$ & \\
\hline & & & & & $\begin{array}{l}\text { - by } 18 \text { months fol- } \\
\text { lowing Ist surgery, } \\
\text { depression and anxiety } \\
\text { improved, but OCD } \\
\text { and tics not improved } \\
\text { - by I3 months } \\
\text { following } 2 \text { nd surgery, } \\
\text { OCD, depression, and } \\
\text { anxiety improved, but } \\
\text { tics worse }\end{array}$ & \\
\hline \multirow[t]{3}{*}{ Kulisevsky et al 1995} & $\begin{array}{l}\text { Case } \\
\text { report }\end{array}$ & 1 & OCD & $\begin{array}{l}\text { Leucotomy } \\
\text { (bilateral prefrontal) }\end{array}$ & - Follow-up: 39 years & $\begin{array}{l}\text { - bulimia, weight gain, } \\
\text { compulsive smoking } \\
\text { appeared } 4 \text { years after } \\
\text { surgery and deemed } \\
\text { to be surgical }\end{array}$ \\
\hline & & & & & $\begin{array}{l}\text { • Evaluation:YBOCS, } \\
\text { LOI, HDRS TBSA,TSGS }\end{array}$ & surgical side effects \\
\hline & & & & & $\begin{array}{l}\text { - Disappearance of } \\
\text { coprolalia, copropraxia, } \\
\text { and OCD } 5 \text { years after } \\
\text { surgery that recurred } \\
38 \text { years later }\end{array}$ & \\
\hline Korzenev et al 1997 & $\begin{array}{l}\text { Case } \\
\text { series }\end{array}$ & 4 & OCD & $\begin{array}{l}\text { Details regarding the lesion } \\
\text { targets, follow-up period, } \\
\text { evaluation techniques and } \\
\text { effects on tics not specified }\end{array}$ & & \\
\hline \multirow[t]{2}{*}{ Babel et al $200 \mathrm{I}$} & $\begin{array}{l}\text { Case } \\
\text { series }\end{array}$ & 16 & $\begin{array}{l}\text { ADHD } \\
\text { (3 patients) }\end{array}$ & ZI, LM,VL & $\begin{array}{l}\text { - Follow-up: } 7 \text { years } \\
\text { (range } 3.5-17 \text { years) } \\
\text { (II patients); } 5 \text { patients } \\
\text { lost to follow-up }\end{array}$ & $\begin{array}{l}\text { - Cerebellar signs, } \\
\text { dystonia, and } \\
\text { dysarthria } \\
\text { (I I patients) }\end{array}$ \\
\hline & & & & $\begin{array}{l}9 \text { patients - bilateral } \\
\text { lesions }\end{array}$ & $\begin{array}{l}\text { - Evaluation:Tic severity } \\
\text { rating scale }\end{array}$ & $\begin{array}{l}\text { - transient } \\
\text { postoperative } \\
\text { morbidity ( } 6 \text { patients) }\end{array}$ \\
\hline
\end{tabular}

(Continued) 
Table I (Continued)

\begin{tabular}{|c|c|c|c|c|c|c|}
\hline Study effects & $\begin{array}{l}\text { Study } \\
\text { design }\end{array}$ & $\mathbf{n}$ & $\begin{array}{l}\text { Comorbid } \\
\text { diagnoses }\end{array}$ & Lesion & Outcomes & Adverse \\
\hline & & & & $\mathrm{Zl}$ targeted in 15 patients & $\begin{array}{l}\text { - significant } \\
\text { improvement of both } \\
\text { vocal and motor tic } \\
\text { scores }(33 \%-75 \% \text { and } \\
25 \%-80 \% \text { in tic severity } \\
\text { reduction, respectively) }\end{array}$ & $\begin{array}{l}\text { - hemiparesis } \\
\text { (3 patients) }\end{array}$ \\
\hline & & & & $\mathrm{ZI}$ and VL/LM in II patients & & $\begin{array}{l}\text { - disabling hemiballism } \\
\text { (I patient) }\end{array}$ \\
\hline \multirow[t]{4}{*}{ Anandan et al 2004} & $\begin{array}{l}\text { Case } \\
\text { report }\end{array}$ & I & $\begin{array}{l}\text { SIB, OCD, } \\
\text { ADHD }\end{array}$ & $\begin{array}{l}\text { Cingulotomy (targeted area } \\
\text { above corpus callosum) and } \\
\text { urinating then limbic leucotomy } \\
\text { ( } 7 \text { months afterwards, targeted } \\
\text { area under caudate nucleus } \\
\text { proximal to previous lesion site) }\end{array}$ & $\begin{array}{l}\text { - Follow-up } \\
\text { (cingulotomy): } \\
6 \text { months }\end{array}$ & $\begin{array}{l}\text { - Cingulotomy: } \\
\text { headaches, difficulty }\end{array}$ \\
\hline & & & & & $\begin{array}{l}\text { - initial period of } \\
\text { improvement of SIB but } \\
\text { then recurrence of tics } \\
\text { and SIB }\end{array}$ & $\begin{array}{l}\text { - Leucotomy } \\
\text { headaches, drowsiness }\end{array}$ \\
\hline & & & & & $\begin{array}{l}\text { - Follow-up } \\
\text { (leucotomy): } \\
\text { not specified }\end{array}$ & \\
\hline & & & & & $\begin{array}{l}\text { - } \downarrow \text { frequency and } \\
\text { severity of SIB }\end{array}$ & \\
\hline \multirow[t]{3}{*}{ Sun et al 2005} & $\begin{array}{l}\text { Case } \\
\text { series }\end{array}$ & 12 & $\begin{array}{l}\text { OCD SIB } \\
\text { (4 patients) }\end{array}$ & $\begin{array}{l}\text { Capsulotomy [targeted the } \\
\text { anterior I/3 ( } 7 \text { patients) } \\
\text { or posterior I/3 ( } 5 \text { patients) } \\
\text { of anterior internal capsule], } \\
\text { bilaterally }\end{array}$ & $\begin{array}{l}\text { - Follow-up: 3-18 } \\
\text { months (mean 13.4) }\end{array}$ & $\begin{array}{l}\text { - no severe, perma- } \\
\text { nent side effects }\end{array}$ \\
\hline & & & & & $\begin{array}{l}\text { - Reduction of tics imme- } \\
\text { diately post-operatively } \\
\text { after anterior internal } \\
\text { capsule lesion; benefits } \\
\text { decreased by I months } \\
\text { post-operatively in } \\
5 \text { patients; only } 2 \text { patients } \\
\text { demonstrated } 80 \% \downarrow \text { in } \\
\text { tics over sustained time } \\
\text { period }\end{array}$ & $\begin{array}{l}\text { - transient urinary } \\
\text { incontinence, memory } \\
\text { complaints, confusion }\end{array}$ \\
\hline & & & & & $\begin{array}{l}\text { - } 4 \text { patients with lesion } \\
\text { of posterior internal } \\
\text { capsule demonstrated } \\
\text { significant and sustained } \\
\text { reduction of tics; } \\
\text { I patient had } 50 \% \downarrow \\
\text { of tics }\end{array}$ & $\begin{array}{l}\text { - delayed side effects: } \\
\text { increased sexual } \\
\text { behavior ( } 3 \text { patients), } \\
\text { immature behavior } \\
\text { ( } 2 \text { patients), akathisia } \\
\text { ( } 2 \text { cases) }\end{array}$ \\
\hline
\end{tabular}

Abbreviations: ADHD, attention deficit hyperactivity disorder; BDI, beck depression inventory; CGI, clinical global improvement scale; HDRS, hamilton depression rating scale; LM, lamella medialis thalamus; LOI, leyton obsessional inventory; OCD, obsessive-compulsive disorder; SIB, self-injurious behaviour; TBSA, tyrer brief scale for anxiety; TSGS, tourette's syndrome global scale; VL, ventrolateral nuclei of the thalamus; YBOCS, yale-brown obsessive compulsive scale; ZI, zona incerta.

surgical disconnection of the frontal lobe. Stevens (1964) reported the details of the prefrontal lobotomy that James Watts had performed nine years earlier in a 37-year-old man who had become incapacitated due to his motor and vocal tics. Two years post-operatively, the patient demonstrated improvement in his symptoms, which persisted for at least an additional six years. His beneficial clinical course could not be attributed entirely to the surgery, however, since 
he also began to use neuroleptics. Baker (1962) reported the apparently successful management of tics and panic attacks in a 22-year-old man with bimedial frontal leucotomy, but Moldofsky and colleagues' (1974) found that these benefits did not persist. The longest reported duration of symptom control attributed to prefrontal leucotomy was that experienced by a 29 -year-old man with TS in whom there was complete resolution of motor and vocal tics beginning five years post-operatively and for thirty-three years thereafter (Kulisevsky et al 1995). Measurement of regional cerebral blood flow using ${ }^{99} \mathrm{Tc}$-hexamethlypropylene amine oxide SPECT showed bilateral frontal hypoperfusion (Kulisevsky et al 1995).

\section{Cingulotomy}

Demonstration of the efficacy of frontal lobotomy procedures for TS was not clear, and as a result procedures that targeted the cingulate cortex were investigated as an alternative. Anterior cingulotomy had been used since 1948 to treat a variety of psychiatric disorders to disconnect neural circuits involving the cortex, limbic system, and basal ganglia (Whitty et al 1952; Ballantine et al 1987). Targeting the cingulate cortex for the treatment of TS seemed appropriate given its recognized role in mediating emotional experiences and language and coordinated movements (Robertson et al 1990). Cingulotomy decreased tics by $75 \%$ by 2 years post-operatively in one patient (Anandan et al 2004) and provided enduring improvement in another (Sawle et al 1993). In an imaging study that found normalization of preoperative hypermetabolism in the caudate nucleus and thalamus, the beneficial effects of cingulotomy were ascribed nonspecifically to the disruption of abnormal basal ganglia-thalamocortical circuitry (Sawle et al 1993). Other case reports have not confirmed those beneficial effects of cingulotomy and found that the procedure had little effects on reducing either tic severity or frequency or seemed more efficacious for other comorbid symptoms, such as SIB and OCD (Kurlan et al 1988, 1990; Robertson et al 1990; Baer et al 1994). Beckers (1973) has recommended against the use of cingulotomy because of its side effects, which have included the development of apathy, intellectual impairment, and difficulties with concentration.

\section{Thalamotomy}

Attenuation of the corticostriatal hyperactivity that is thought to underlie TS symptomatology has also been attempted by thalamic lesions. Cooper's performance of a right and then, one year later, left chemothalamectomy in a 16-year-old girl with TS significantly improved her tic frequency (Cooper 1962) and he later described his experience with thalamic lesions in six other patients with TS (Cooper 1969). Details for only one representative case were provided, in which surgery had no effect on the tics. The results of Hassler and Dieckeman (1970) were more promising: up to 14 coagulations were made stereotactically in each hemisphere in the medial, intralaminar, and ventrolateral thalamic nuclei and between $70 \%$ and $100 \%$ subjective improvement of tic symptomatology was observed. The same nuclei have been targeted in 4 other reported patients, but complete tic resolution was observed in only one patient, and in the others tic improvement was only transient at best (de Divitiis et al 1977; Cappabianca et al 1987). A case report in which bilateral cingulotomies and infrathalamic lesions were made highlights the potential devastating complications of thalamic lesions (Leckman et al 1993). A 40-year-old man who underwent these procedures demonstrated improvement of obsessive compulsive symptoms but persistence of motor and vocal and the left lesions were therefore repeated (Leckman et al 1993). The infrathalamic lesion was extended inferiorly within the red nucleus and included as well the $\mathrm{H}$ fields of Forel, the basal intralaminar nucleus of the thalamus, the subthalamic nucleus, efferent fibres from the VTA and SNr, and the dentatorubrothalamic efferent fibres from the cerebellum (Leckman et al 1993). Post-operatively the patient developed a number of severe neurological deficits including dysarthria, dysphagia, gait and hand-writing difficulties, mild hemiparesis, abnormal extraocular movements, axial rigidity, and bradykinesia (Leckman et al 1993).

\section{Lesions of other structures}

Stereotaxy has facilitated the targeting of other deep-seated cerebral structures for the treatment of TS. In combination with lesions of the lamella medialis and ventrolateral nuclei of the thalamus, the zona incerta has been lesioned with significant reduction of tic severity (Babel et al 2001). Transient and permanent deficits were experienced by $66 \%$ and $27 \%$ of patients (Babel et al 2001), with bilateral lesions carrying a higher risk of neurological morbidity, including hemiballism, dystonia, dysarthria (Babel et al 2001), and quadriplegia (Asam and Karrass 1981). Other structures targeted include the anterior limb of the internal capsule (Sun et al 2005), within which striatal circuits and circuits that connect orbitofrontal cortical and medial thalamic nuclei pass. Lesions of the posterior third of the anterior internal capsule provided more durable improvement of symptoms, 
which was thought to be due the greater efficacy of posterior lesions to disrupt neural pathways connecting the basal ganglia and frontal cortex (Sun et al 2005). In one case report, lesions of the dentate nucleus reportedly attenuated motor and vocal tics, but neither rationale for targeting this cerebellar structure nor a proposed mechanism of beneficial action were discussed (Nádvorník et al 1972).

\section{Deep brain stimulation}

Although neurosurgical lesions for TS have ameliorated symptoms for some patients, for others, benefits have not been apparent and lesions have been associated with a number of permanent and disabling side effects. Deep brain stimulation (DBS) emerged as a promising alternative therapeutic strategy to stereotactic lesions after its efficacy in the treatment of tremor was demonstrated in 1987 (Benabid et al 1987). The similar clinical effects of lesions and high frequency stimulation (HFS) suggest that DBS may inhibit the activity of target structures, by depolarization blockade, synaptic inhibition, and/or the release of inhibitory neurotransmitters (Benazzouz and Hallet 2000; Dostrovsky et al 2002; Filali et al 2004; Lozano and Mahat 2004; McIntyre et al 2004; Chang et al 2008; Liu et al 2008; Montgomery and Gale 2008). Other studies suggest, however, that DBS has an excitatory effect on neurons and axonal pathways in the vicinity of the electrode (McIntyre et al 2004; Chang et al 2008; Liu et al 2008; Montgomery and Gale 2008), or that DBS works by modulating the pattern of neuronal firing (Fukada et al 2001; Garcia et al 2005; Change et al 2008; Liu et al 2008; Montgomery and Gale 2008). Regardless of its mechanism of action, compared to lesion procedures DBS has the advantage of being both reversible (since the electrodes can be removed if HFS ineffectively treats symptoms) and adjustable (since the stimulation parameters can be varied to elicit the most optimal clinical response). Benabid (2007) has thus referred to DBS as a "flexible scalpel."

\section{Thalamic stimulation}

Based upon the reported success of thalamic lesions in the control of TS symptoms, Visser-Vandewalle and colleagues (1999) performed HFS of the thalamus in a 42-year-old man with medically recalcitrant TS (Table 2). They found that HFS of the thalamic targets of Hassler and Dieckemann (1970) significantly reduced the number of tics by 4 months post-operatively, with complete resolution of the tics after 1 year. Clinical benefits were ascribed to deactivation of frontal cortical areas (via stimulation of the nucleus ventro-oralis internus) and corticostriatal circuits that involve the ventral (limbic) and dorsal (sensorimotor) striatum (via stimulation of intralaminar and medial thalamic nuclei). In a subsequent study in which three patients were followed up to five years post-operatively, thalamic DBS was associated with a $72 \%, 83 \%$, and $90 \%$ decrease in tics with complete resolution of all major vocal and motor tics (VisserVandewalle et al 2003). Side effects of HFS included a slight sedative effect in all three patients and changes in sexual behavior in two (Visser-Vandewalle et al 2003). Servello and colleagues (2008) confirmed the therapeutic efficacy of thalamic DBS, albeit using targets different than those used by Visser-Vandewalle and colleagues, in their case series of eighteen patients in whom the centromedian-parafascicular and ventral oral thalamic nuclei were targeted. All patients demonstrated improvement in all four components of the Yale Global Tic Severity Rating Scale (YGTSS). By six months post-operatively, 3 patients' tics had improved to the extent that they no longer required any adjunctive medical therapy. None of the patients experienced any disabling permanent side effects, but twelve patients required HFS adjustments. The ability for the effects of DBS to be tested in a double-blind manner was utilized in a recent prospective crossover trial (Maciunas et al 2007). Patients in whom bilateral thalamic DBS electrodes were implanted were assessed over four weeks, with one week spent in each of the following DBS states: both stimulators off, unilateral stimulation on the left or right, or bilateral stimulation (Maciunas et al 2007). The study's primary and secondary outcome measures were met in that all patients demonstrated significant improvements in Rush Video-Based Rating Scale (RVBRS) scores as well as YGTSS and TS Symptom List scores (Maciunas et al 2007). Ackermans and colleagues' (2007) case report highlights that significant adverse effects can occur due to the thalamic DBS. Their 39-year-old patient developed a vertical gaze paralysis due to hemorrhage in the upper mesencephalon at the caudal tip of one of the electrodes.

\section{Pallidal stimulation}

Attenuation of thalamic activity, indirectly, has also been attempted by HFS of the GPi in order to inhibit its pathological over-activity that is thought to ultimately lead to disinhibition of the thalamus and, thus, tics (van der Linden et al 2002; Diederich et al 2005; Houeto et al 2005; Ackermans et al 2006; Gallagher et al 2006; Shahed et al 2007). van der Linden and colleagues (2002) found that bilateral GPi DBS decreased tics by $95 \%$ in a 27 -year-old man with long-standing TS, which was greater than the suppression of tics induced by medial thalamic DBS (80\%), 
Table 2 Clinical studies of deep brain stimulation for Tourette's syndrome

\begin{tabular}{|c|c|c|c|c|c|c|}
\hline Study & $\begin{array}{l}\text { Study } \\
\text { design }\end{array}$ & $\mathbf{n}$ & $\begin{array}{l}\text { Comorbid } \\
\text { diagnoses }\end{array}$ & DBS target(s) & Outcomes & Adverse effects \\
\hline \multirow[t]{4}{*}{ Vandewalle et al 1999} & Case report & 1 & - & $\begin{array}{l}\text { Thalamus } \\
\text { (rostral } \\
\text { intralaminar and } \\
\text { medial nuclei) } \\
\text { bilaterally }\end{array}$ & - Follow-up: I year & - none reported \\
\hline & & & & & - Evaluation: videotape & \\
\hline & & & & & analysis of tics & \\
\hline & & & & & $\begin{array}{l}\text { - complete abolishment } \\
\text { of tics }\end{array}$ & \\
\hline \multirow[t]{5}{*}{$\begin{array}{l}\text { van der Linden et al } \\
2002\end{array}$} & Case report & 1 & depression & $\begin{array}{l}\text { Thalamus } \\
\text { (medial) and GPi } \\
\text { bilaterally }\end{array}$ & - Follow-up: 6 months & - none reported \\
\hline & & & & & - Evaluation: not specified & \\
\hline & & & & & - $80 \% \downarrow$ tics by thalamic & \\
\hline & & & & & DBS & \\
\hline & & & & & - $95 \% \downarrow$ tics by pallidal DBS & \\
\hline \multirow[t]{4}{*}{$\begin{array}{l}\text { Visser-Vandewalle } \\
\text { et al } 2003\end{array}$} & Case series & 3 & - & $\begin{array}{l}\text { Thalamus (at level } \\
\text { of the Voi, Cm, } \\
\text { Spv) bilaterally }\end{array}$ & $\begin{array}{l}\text { - Follow-up: } 8 \text { months } \\
-5 \text { years }\end{array}$ & $\begin{array}{l}\text { - reduced energy } \\
\text { at stimulus voltage } \\
\text { required for optimal tic } \\
\text { management }\end{array}$ \\
\hline & & & & & $\begin{array}{l}\text { - Evaluation: videotape } \\
\text { analysis of tics }\end{array}$ & $\begin{array}{l}\text { - increased sexual drive } \\
\text { (I patient) }\end{array}$ \\
\hline & & & & & $\begin{array}{l}\text { - Resolution of all major } \\
\text { tics }\end{array}$ & $\begin{array}{l}\text { - reduced sexual } \\
\text { function (I patient) }\end{array}$ \\
\hline & & & & & & $\begin{array}{l}-3 \text { revisions of pulse } \\
\text { and cables because of } \\
\text { pain generator traction } \\
\text { ( } 2 \text { patients) }\end{array}$ \\
\hline \multirow[t]{6}{*}{ Flaherty et al 2005} & Case report & I & - & $\begin{array}{l}\text { AIC (ventral) } \\
\text { bilaterally }\end{array}$ & - Follow-up: 18 months & $\begin{array}{l}\text { - mood alteration (high } \\
\text { nucleus voltage stimula- } \\
\text { tion at depression } \\
\text { accumbens produced } \\
\text { at and apathy, stimula- } \\
\text { tion capsule in body } \\
\text { of internal produced } \\
\text { hypomania) }\end{array}$ \\
\hline & & & & & - Evaluation:YGTSS & \\
\hline & & & & & $\begin{array}{l}\cdot 25 \% \downarrow \text { YGTSS in overall } \\
\text { impairment }\end{array}$ & \\
\hline & & & & & - $17 \% \downarrow$ total tic score & \\
\hline & & & - & & - $20 \% \downarrow$ global severity & \\
\hline & & & & & $\begin{array}{l}-45 \% \downarrow \text { tic severity and } \\
\text { frequency and increased } \\
\text { ability to suppress tics } \\
\text { (according to patient) }\end{array}$ & \\
\hline \multirow[t]{2}{*}{ Diederich et al 2005} & Case report & I & mild OCD & GPi bilaterally & - Follow-up:I4 months & $\begin{array}{l}\text { - transient fatigue } \\
\text { (several months) }\end{array}$ \\
\hline & & & & & $\begin{array}{l}\text { • Evaluation:YGTSS, BDI, } \\
\text { STAI, SCL-90-R }\end{array}$ & $\begin{array}{l}\text { - impaired rapidly } \\
\text { alternating pronation } \\
\text { and supination } \\
\text { movements of left limbs }\end{array}$ \\
\hline
\end{tabular}


Table 2 (Continued)

\begin{tabular}{|c|c|c|c|c|c|c|}
\hline Study & $\begin{array}{l}\text { Study } \\
\text { design }\end{array}$ & $\mathbf{n}$ & $\begin{array}{l}\text { Comorbid } \\
\text { diagnoses }\end{array}$ & DBS target(s) & Outcomes & Adverse effects \\
\hline & & & & & - $73 \% \downarrow$ tic frequency /minute & \\
\hline & & & & & - $\downarrow$ intensity of vocal tics & \\
\hline \multirow[t]{8}{*}{ Houeto et al 2005} & $\begin{array}{l}\text { Prospective } \\
\text { double blind }\end{array}$ & 1 & $\begin{array}{l}\text { Anxiety Depression } \\
\text { SIB }\end{array}$ & $\begin{array}{l}\text { Ce-Pf of thalamus, } \\
\text { GPi, or both }\end{array}$ & - Follow-up: 2 years & - weight loss \\
\hline & & & & & $\begin{array}{l}\text { - Evaluation:YGTSS, RVB- } \\
\text { TRS, MADRS, BAS, BIS }\end{array}$ & \\
\hline & & & & & $\begin{array}{l}\cdot \text { Thalamic DBS: } 64 \% \downarrow \\
\text { YGTSS scores, } 77 \% \downarrow \\
\text { RVBTS scores }\end{array}$ & \\
\hline & & & & & $\begin{array}{l}\text { - Pallidal DBS: } 66 \% \downarrow \text { YGTSS } \\
\text { scores, } 54 \% \downarrow \text { RVBTS } \\
\text { scores }\end{array}$ & \\
\hline & & & & & - combined DBS: $60 \% \downarrow$ & \\
\hline & & & & & YGTSS scores, $77 \% \downarrow$ & \\
\hline & & & & & RVBTS scores & \\
\hline & & & & & - elimination of SIB & \\
\hline \multirow[t]{4}{*}{ Ackermans et al 2006} & Case series & 2 & OCD & $\begin{array}{l}\text { Patient I: } \\
\text { Thalamus } \\
\text { (at level of Voi, } \\
\text { Cm, and Spv) } \\
\text { bilaterally }\end{array}$ & - Follow-up: I year & $\begin{array}{l}\text { - feeling of } \downarrow \text { energy } \\
\text { at required stimulus } \\
\text { voltage reduction for } \\
\text { optimal tic }\end{array}$ \\
\hline & & & & & $\begin{array}{l}\text { - Evaluation:Videotaping and } \\
\text { counting tics }\end{array}$ & - $\downarrow$ sexual functions \\
\hline & & & & $\begin{array}{l}\text { Patient 2:Thalamus } \\
\text { (at level of Voi, Cm, } \\
\text { and Spv) and GPi } \\
\text { (postero ventro- } \\
\text { lateral) bilaterally }\end{array}$ & $\begin{array}{l}-\downarrow \text { tics [from } 20 \text { to } \\
3 / \text { minute (patient I) and } \\
28 \text { to } 2 / \text { minute (patient } 2 \text { )] }\end{array}$ & $\begin{array}{l}\text { - dystonic jerk when } \\
\text { stimulator activated }\end{array}$ \\
\hline & & & & & $\begin{array}{l}\text { - Complete resolution of all } \\
\text { major tics and compulsions }\end{array}$ & \\
\hline Gallagher et al 2006 & Case report & 1 & - & GPi bilaterally & $\begin{array}{l}\text { - Follow-up: "months" (time } \\
\text { not specified) } \\
\text { - evaluation of tics not } \\
\text { discussed }\end{array}$ & $\begin{array}{l}\text { - Infection of } \\
\text { stimulator lead }\end{array}$ \\
\hline Ackermans et al 2007 & Case report & 1 & SIB & $\begin{array}{l}\text { Thalamus } \\
\text { (medial part at } \\
\text { crosspoint of } \mathrm{Cm} \text {, } \\
\text { Voi, hemorrhage } \\
\text { and Spv) } \\
\text { bilaterally }\end{array}$ & $\begin{array}{l}\text { - effects on tics not } \\
\text { discussed }\end{array}$ & $\begin{array}{l}\text { - vertical gaze palsy due } \\
\text { to intracerebral }\end{array}$ \\
\hline \multirow[t]{5}{*}{ Kuhn et al 2007} & Case report & 1 & OCD & $\begin{array}{l}\text { nucleus accumbens } \\
\text { and anterior limb of } \\
\text { the internal capsule }\end{array}$ & - Follow-up: 2.5 years & - none reported \\
\hline & & & & & $\begin{array}{l}\text { - Evaluation:YGTSS, MRVRS, } \\
\text { GAF,YBOCS }\end{array}$ & \\
\hline & & & & & $\begin{array}{l}-41 \%, 50 \% \text {, and } 52 \% \\
\text { remission rates in YGTSS, } \\
\text { MRVRS, and YBOCS, } \\
\text { respectively }\end{array}$ & \\
\hline & & & & & - considerable improvement & \\
\hline & & & & & $\begin{array}{l}\text { in psycho-social functioning } \\
\text { (GAF } \uparrow \text { from } 7 \text { to } 4 \mathrm{I} \text { ) }\end{array}$ & \\
\hline
\end{tabular}

(Continued) 
Table 2 (Continued)

\begin{tabular}{|c|c|c|c|c|c|c|}
\hline Study & $\begin{array}{l}\text { Study } \\
\text { design }\end{array}$ & $\mathrm{n}$ & $\begin{array}{l}\text { Comorbid } \\
\text { diagnoses }\end{array}$ & DBS target(s) & Outcomes & Adverse effects \\
\hline \multirow[t]{5}{*}{ Maciunas et al 2007} & $\begin{array}{l}\text { Prospective, } \\
\text { randomized, } \\
\text { double-blind, } \\
\text { crossover }\end{array}$ & 5 & $\begin{array}{l}\text { ADHD } \\
\text { ( } 3 \text { patients) OCD } \\
\text { (4 patients) } \\
\text { depression } \\
\text { (5 patients) }\end{array}$ & $\begin{array}{l}\text { Thalamus } \\
\text { (Cm, Voi, and Spv) } \\
\text { bilaterally }\end{array}$ & - Follow-up: 3 months & $\begin{array}{l}\text { - none related to the } \\
\text { procedures }\end{array}$ \\
\hline & & & & & $\begin{array}{l}\text { • Evaluation:YGTSS, SF-36, } \\
\text { VAS, BDI-2, HAM-D, HAM-A, } \\
\text { YBOCS TSSL, MRVRS }\end{array}$ & \\
\hline & & & & & $\begin{array}{l}\text { - Significant } \downarrow \text { in MRVRS } \\
\text { (primary outcome measure) } \\
\text { in bilateral on state }\end{array}$ & \\
\hline & & , & & & $\begin{array}{l}\text { - Significant improvement in } \\
\text { tic counts and YGTSS and } \\
\text { TSLS scores (secondary } \\
\text { outcome measures) }\end{array}$ & \\
\hline & & & & & $\begin{array}{l}\text { - Quality of life indices } \\
\text { improved (SF-36 and VAS } \\
\text { scores) }\end{array}$ & \\
\hline \multirow[t]{6}{*}{ Shahed et al 2007} & Case report & 1 & $\begin{array}{l}\text { OCD,ADHD, } \\
\text { Depression, anxiety }\end{array}$ & GPi bilaterally & - Follow-up: 6 months & - none reported \\
\hline & & & & & $\begin{array}{l}\text { • Evaluation:YGTSS,TSSR, } \\
\text { MRVRS YBOCS, SF-36 v2, } \\
\text { BRIEF }\end{array}$ & \\
\hline & & & & & $\cdot 84 \% \downarrow$ total YGTSS scores & \\
\hline & & & & & $\cdot 88 \% \downarrow$ TSSR scores & \\
\hline & & & & & $\cdot 21 \% \downarrow$ MRVRS scores & \\
\hline & & & & & - $65 \% \uparrow \mathrm{SF}-36 \mathrm{v} 2$ scores & \\
\hline \multirow[t]{5}{*}{ Servello et al 2008} & Case series & 18 & $\begin{array}{l}\text { OCD ( } 9 \text { patients) } \\
\text { SIB ( } 9 \text { patients) } \\
\text { Depression } \\
\text { ( } 3 \text { patients) ADHD } \\
\text { (I patient) }\end{array}$ & $\begin{array}{l}\text { Thalamus (Ce-Pf } \\
\text { and Voi) bilaterally }\end{array}$ & - Follow-up: 3-18 months & - none reported \\
\hline & & & & & - Evaluation:YGTSS & \\
\hline & & & & & - $65 \% \downarrow$ in YGTSS scores & \\
\hline & & & & & $\begin{array}{l}\text { - I7 patients demonstrated } \\
\text { significant improvement of } \\
\text { tic severity }\end{array}$ & \\
\hline & & & & & $\begin{array}{l}\text { - } 3 \text { patients required no } \\
\text { further medical Therapy }\end{array}$ & \\
\hline
\end{tabular}

Abbreviations: ADHD, attention deficit hyperactivity disorder;AIC, anterior internal capsule; BAS, brief anxiety scale; BDI, beck depression inventory; BIS, baratt's impulsivity scale; BRIEF, behaviour rating inventory of executive function; Ce-Pf, centromedian-parafascicular complex of the thalamus; Cm, centromedian nucleus; GAF, global assessment of functioning scale; GPi, globus pallidus pars internus; HAM-A, hamilton rating scale for anxiety; HAM-D, hamilton rating scale for depression; MADRS, montgomery-asberg depression rating scale; MRVRS, modified rush video rating scale; OCD, obsessive-compulsive disorder; RVBTS, rush video-based tic rating scale; Spv, substantia periventricularis; SCL-90-R, symptom checklist-90-R;SF-36, short form 36;SIB, self-injurious behaviour;STAl, state-trait anxiety Inventory;TSSL, tourette syndrome symptom list;TSSR, tic symptom self-report; v2, version 2;VAS, visual analog scale; Voi, nucleus ventro-oralis internus; YBOCS, yale-brown obsessive-compulsive scale; YGTSS, yale global tic severity scale.

an effect that lasted at least six months. The efficacy of thalamic or pallidal DBS was found to be similar in another case report, although tic attenuation occurred more abruptly with pallidal stimulation (Ackermans et al 2006). Houeto and colleagues (2005) also directly compared the efficacy of pallidal versus thalamic DBS in their prospective double blind study. In one patient in whom electrodes were placed in the anteromedial GPi and centromedian-parafascicular complex of the thalamus, either thalamic or pallidal stimulation significantly reduced tic severity and SIB to a 
similar extent. Symptoms relating to mood and impulsivity were better controlled by thalamic DBS, however. Diederich and colleagues (2005) provide up to fourteen months of follow-up data regarding their patient with bilateral DBS of the posteroventrolateral GPi. Tic frequency and intensity improved, as did the patient's concomitant anxious and depressive symptoms. These beneficial effects have been observed in two other case reports (Gallagher et al 2006; Shahed et al 2007).

\section{Other targets for stimulation therapy}

Other less frequently targeted structures include the anterior limb of the internal capsule and the nucleus accumbens (Flaherty et al 2005; Kuhn et al 2007). Using a more lateral and anterior target than has been used for the surgical treatment of OCD, DBS of the anterior limb of the internal capsule has been shown to decrease tic severity and frequency, but not to the extent that has been observed with thalamic DBS (Flaherty et al 2005). Stimulation of the electrode's middle contacts resulted in the greatest improvement of tic symptomatology (Flaherty et al 2005). Interestingly, variation in voltage parameters affected the patient's mood: HFS in the middle or dorsal-most contacts, which lay in the body of internal capsule, produced euthymia and hypomania, respectively, whereas stimulation of the ventral-most contacts, which was located near the nucleus accumbens, caused depression (Flaherty et al 2005). Kuhn and colleagues (2007) did not report any alteration of mood in their case report of HFS of the anterior limb of the internal capsule and fundus subventricularis of the nucleus accumbens, and found that it decreased their 26-year-old patient's YGTSS and RVBRS scores by $41 \%$ and $50 \%$, respectively.

\section{DBS caveats}

Despite their therapeutic promise for TS and apparent advantages compared with neurosurgical lesion procedures, DBS strategies also can be associated with a number of deleterious side effects and complications. While certain adverse events are common to both lesion and DBS procedures, such as intracerebral hemorrhage ${ }^{1}$ and the development of surgery-related infection or seizures

\footnotetext{
${ }^{1}$ The reported incidence of symptomatic intracerebral hemorrhage associated with stereotactic procedures ranges from $0.6 \%$ to $2.1 \%$, with age, male sex, Parkinson's disease, and hypertension found to be significant risk factors (Beric et al 2001; Favre et al 2002; Lyons et al 2004; Binder et al 2005; Gorgulho et al 2005; Sansur et al 2007). It has been found that the incidence of intracerebral hemorrhage following either thalamic DBS or ablative thalamic lesions for parkinsonian tremor is not significantly different (Blomstedt and Hariz 2006).
}

(Hardesty and Sackheim 2007), others are unique to DBS. For example, patients with TS in whom DBS systems have been implanted have experienced poor healing, infections, or hardware malfunctions due to compulsions to repeatedly touch their incisions or push on the subcutaneously-buried hardware (Servello et al 2008; Shahed et al 2007; Sillay et al 2008). Limousin-Downey and Tisch (2005) suggest that patients with comorbid OCD symptoms may become obsessed with their DBS systems in terms of thoughts of "mind control". Moreover, DBS requires ongoing surgical maintenance to replace pulse generators (Bin-Mahfoodh et al 2003), which last between several months to five years depending upon stimulation parameters, manage hardwarerelated complications (Oh et al 2002; Temel et al 2004; Constantoyannis et al 2005; Hamani and Lozano 2006), which have been noted to occur in up to $26 \%$ of cases, or adjust the stimulation settings. As has been reported for patients who have received DBS for Parkinson's disease, HFS for TS may induce or exacerbate pre-existing psychiatric symptoms (Appleby et al 2007).

\section{Surgical considerations}

With DBS emerging as a promising therapeutic strategy for the management of TS, guidelines have been proposed regarding its use (Mink et al 2006; Hardesty and Sackeim 2007; Okun et al 2008). Since TS symptoms, especially motor symptoms, may dissipate in late adolescence (Leckman et al 1998), it has been suggested that surgical candidates be at least twenty-five years of age, although Mink and colleagues (2006) acknowledge that selection of that age is somewhat arbritary. Patient selection should occur in a standardized manner. Patients should have their diagnosis of TS confirmed by two independent clinicians and demonstrate recalcitrance to nonsurgical therapies (Singer et al 2001; Minks et al 2006; Visser-Vandewalle 2007). Visser-Vandewalle (2007) suggests that this entails a lack of, or at best only partial, response to three different classes of medications (antidopaminergic, antipsychotic, and experimental agents) and behavioral therapies. Patients should have tics severe enough to significantly impair quality of life and/or pose medical risk, and this is suggested to correspond to a YGTSS total tic severity score of $>35 / 50$ for at least one year (which corresponds to tics that are frequent and noticeable in most situations most of the time) (Mink et al 2006). Patients unsuitable for surgical management include those who have a disorder other than TS, other severe psychiatric co-morbidities, structural cerebral abnormalities, or who have medical contraindications to undergoing surgery (Mink et al 2006; Visser-Vandewalle 2007). It is mandatory 
that an ethics review board oversee DBS clinical trials and that a multidisciplinary team provides ongoing input into clinical trial design and evaluation (Fins 2003; Nuttin and Gybels 2003; Gilbert 2006; Hamani and Moro 2007). Patients should be assessed using validated and standardized tests (Müller-Vahl 2002), such as the YGTSS (Harcherik et al 1984), RVBRS, Shapiro TS Severity Scale (Shapiro et al 1988), and TS Symptom List (Leckman et al 1988), as well as a battery of neuropsychological tests (Mink et al 2006; Visser-Vandewalle 2007). Preoperatively, MRI should be performed to facilitate stereotactic planning and post-operatively, imaging is mandatory to confirm electrode placement (Mink et al 2006). This would additionally provide visualization of the centre of the active contact of stimulation, the positioning of which is crucial to avoid DBS failure (Okun et al 2005). Since insertion of DBS electrodes can cause a microlesion effect (Houeto et al 2005), post-operative assessments of DBS efficacy should be performed after these possible effects have resolved and after stimulation parameters have stabilized (Visser-Vandewalle 2007). Assessment of DBS effects is recommended to be performed in a double-blind fashion. Since DBS for TS remains an experimental therapy, its performance should be limited to neurosurgical centres with DBS experience in the treatment of movement disorders and with collaborations with neurological and psychiatric services (Visser-Vandewalle 2007; Visser-Vandewalle et al 2006). As is standard with other therapies, patients must be able to provide informed consent to participate in clinical trials and should be allowed to withdraw from DBS management at any time (Mink et al 2006; Nuttin and Gybels 2003). The aim of DBS for TS is solely to relieve patients of their symptoms and not for political, law enforcement, or social purposes (Kopell et al 2004).

\section{Conclusions}

In any scientific treatment which is not fully understood there is the serious danger of not being able to predict possible damage. It should be an inflexible duty to become thoroughly familiar with the drug or procedure to be employed. This implies a thorough understanding of the physiological and psychobiological functions which may have a bearing on the proposed treatment (Diethelm 1939).

Oskar Diethelm's (1939) advice at that 1938 Annual Meeting of the American Psychiatric Association bears relevance even seventy years later. Neurosurgical lesion procedures and DBS have demonstrated therapeutic promise for a subset of patients with TS but have not yet provided sufficient evidence to justify their use as standard therapies for TS. Lesion studies provided the proof-of-principle that TS symptoms could be treated using surgery to target specific cerebral structures, but are limited by methodologic issues in study design, such as their open-label nature (see Table 1), unclear patient inclusion and exclusion criteria, and lack of post-operative assessment of the size and location of the lesions performed. To date, most surgical experiences with DBS also have been described in open-label case reports or series with varying degrees of success and with inconsistency in the types of post-operative assessments performed (Temel and Visser-Vandewalle 2004; Neimat et al 2006). Ultimately, improvement of the efficacy of surgical strategies for TS will require identification of the patients whose tics are most likely to respond to HFS, performing comprehensive pre-and post-operative blinded and standardized clinical assessments of tic symptoms, and determination of the most appropriate surgical target(s) for resolution of tic symptomatology. It is anticipated that the development of animal models of TS as well as further advances in anatomical and functional imaging technologies will enhance understanding of TS pathophysiology and so lead to the refinement of current surgical strategies (Sachdev and Sachdev 1997; Sakas et al 2007).

\section{Acknowledgments}

KM acknowledges the generous support of a Killam Scholarship. Work in the Cell Restoration Laboratory is supported by funding from the Stem Cell Network and Atlantic Innovation Fund.

\section{References}

Ackermans L, Temel Y, Bauer NJC, et al. 2007. Vertical gaze palsy after thalamic stimulation for Tourette syndrome: case report. Neurosurgery, 61:E1100

Ackermans L, Temel Y, Cath D, et al. 2006. Deep brain stimulation for Tourette's syndrome: two targets? Mov Disord, 21:709-13.

Albin RL, Koeppe RA, Bohnen NI, et al. 2003. Increased ventral striatal monoaminergic innervations in Tourette syndrome. Neurology, 61:310-5.

Alex KD, Yavanian GJ, McFarlane HG, et al. 2005. Modulation of dopamine release by striatal 5-HT2C receptors. Synapse, 55:242-51.

Alexander GE, DeLong MR. 1985. Microstimulation of the primate striatum. II. Somatotopic organization of striatal microexcitable zones and their relation to neuronal response properties. $J$ Neurophysiol, 53:1417-30.

Anandan S, Wigg CL, Thomas CR, et al. 2004. Psychosurgery for self-injurious behaviour in Tourette's disorder. J Child Adolesc Psychopharmacol, 14:531-8.

Anderson G, Pollak E, Chatterjee D, et al. 1992. Postmortem analysis of subcortical monamines and amino acids in Tourette syndrome. $A d v$ Neurol, 58:123-33.

Appleby BS, Duggan PS, Regenberg A, et al. 2007. Psychiatric and neuropsychiatric adverse events associated with deep brain stimulation: a meta-analysis of ten years' experience. Mov Disord, 22:1722-8.

Asam U, Karrass W. 1981. Gilles de la Tourette syndrome and psychosurgery. Acta Paedopsychiatr, 47:39-48. 
Babel TB, Warnke PC, Ostertag CB. Immediate and long term outcome after infrathalamic and thalamic lesioning for intractable Tourette's syndrome. 2001. J Neurol Neurosurg Psychiatry, 70:666-71.

Baer L, Rauch SL, Jenike MA, et al. 1994. Cingulotomy in a case of concomitant obsessive-compulsive disorder and Tourette's syndrome. Arch Gen Psychiatry, 51:73-4.

Baker EFW. 1962. Gilles de la Tourette syndrome treated by bimedial frontal leucotomy. Can Med Assoc J, 86:746-7.

Ballantine HT, Boukoms, AJ, Thomas EK, et al. 1987. Treatment of psychiatric illness by stereotactic cingulotomy. Biol Psychiatry, 22:807-9.

Balthasar K. 1957. Über das anatomische Substrat de generalisierten Tic-Krankheit (maladie des tics, Gilles de la Tourette): Entwicklungshemmung des corpus striatum. Archiv für Psychiatrie und Nervenkrankheiten, 195:531-49.

Baym CL, Corbett BA, Wright SB, et al. 2008. Neural correlates of tic severity and cognitive control in children with Tourette syndrome. Brain, 131:165-79.

Beard GM. 1880-1881. Experiments with the 'jumpers' or 'jumping Frenchmen' of Maine. Pop Sci Month (NY), 18:170.

Beckers W. 1973. Gilles de la Tourette's disease based on five own observations. Arch Psychiatr Nervenkr, 217:169-86.

Benabid AL, Pollak P, Louveau A, et al. 1987. Combined (thalamotomy and stimulation) stereotactic surgery of the VIM thalamic nucleus for bilateral Parkinson disease. Appl Neurophysiol, 50:344-6.

Benabid AL. 2007. What the future holds for deep brain stimulation. Expert Rev Med Devices, 4:895-903.

Benazzouz A, Hallet M. 2000. Mechanism of action of deep brain stimulation. Neurology, 55(Suppl 6):S13-16.

Beric A, Kelly PJ, Rezai A, et al. 2001. Complications of deep brain stimulation surgery. Stereotact Funct Neurosurg, 77:73-8.

Binder DK, Rau GM, Starr PA. 2005. Risk factors for hemorrhage during microelectrode-guided deep brain stimulator implantation for movement disorders. Neurosurgery, 56:722-32.

Bin-Mahfoodh M, Hamani C, Sime E, et al. 2003. Longevity of batteries in internal pulse generators used for deep brain stimulation. Stereotact Funct Neurosurg, 80:56-60.

Bloch MH, Leckman JF, Zhu H, et al. 2005. Caudate volumes in childhood predict symptom severity in adults of Tourette syndrome. Neurology, 65:1253-8.

Blomstedt P, Hariz MI. 2006. Are complications less common in deep brain stimulation than in ablative procedures for movement disorders? Stereotact Funct Neurosurg, 84:72-81.

Bohlhalter S, Goldfine A, Matteson S, et al. 2006. Neural correlates of tic generation in Tourette syndrome: an event-related functional MRI study. Brain, 129:2029-37.

Bruun RD, Budman CL. 1992. The natural history of Tourette syndrome. Adv Neurol 58:1-6.

Butler IJ, Koslow SH, Seifert WE Jr, et al. 1979. Biogenic amine metabolism in Tourette syndrome. Ann Neurol, 27:443-6.

Campbell KM, Veldman MB, McGrath MJ, et al. 2000. TS+OCD-like neuropotentiated mice are supersensitive to seizure induction. Neuroreport, 11:2335-8.

Cappabianca P, Spaziante R, Carrabs G, et al. 1987. Surgical stereotactic treatment for Gilles de la Tourette's syndrome. Acta Neurol (Napoli), 9:273-80.

Carta M, Carlsson T, Kirik D, et al. 2007. Dopamine released from 5-HT terminal is the cause of L-DOPA-induced dyskinesias in parkinsonian rats. Brain, 130:1819-33.

Castellanos FX, Fine EJ, Kaysen DL, et al. 1996. Sensorimotor gating in boys with Tourette's Syndrome and ADHD: preliminary results. Biol Psychiatry, 39:33-41.

Chang J-Y, Shi L-H, Luo F, et al. 2008. Studies of the neural mechanisms of deep brain stimulation in rodent models of Parkinson's disease. Neurosci Biobehav Rev, 32:352-66.

Cheon KA, Ryu YH, Namkoong K, et al. 2004. Dopamine transporter density of the basal ganglia assessed with [123I]IPT-SPECT in drug-naive children with Tourette's disorder. Psychiatry Res, 130:85-95.
Comings DE. 1990. Blood serotonin and tryptophan in Tourette syndrome. Am J Med Genet, 36:418-30.

Como P. 1995. Obsessive-compulsive disorder in Tourette's syndrome. Adv Neurol 65:281-91.

Constantoyannis C, Berk C, Honey CR, et al. 2005. Reducing hardware-related complications of deep brain stimulation. Can J Neurol Sci, 32:194-200.

de Divitiis E, D’Errico A, Cerillo A. 1977. Stereotactic surgery in Gilles de la Tourette syndrome. Acta Neurochir (Wien), Suppl 24:73.

Demirkiran M, Jankovic J. 1995. Paroxysmal dyskinesias: clinical features and classification. Ann Neurol 38:571-9.

Denkla BM, Harris EL, Aylward EH, et al. 1991. Executive function and volume of the basal ganglia in children in with Tourette syndrome and attention deficit hyperactivity disorder. Ann Neurol, 30:476.

DeWulf A, van Bogaert L. 1941. Etudes anatomo-cliniques des syndromes hypercinétiques complexes, III. Une observation anatomo-clinique de maladie des tics (Gilles de la Tourette). Monatsschrift für Psychiatrie und Neurologie, 104:53-61.

Diederich NJ, Kalteis K, Stamenkovic M, et al. 2005. Efficient internal pallidal stimulation in Gilles de la Tourette Syndrome: a case report. Mov Disord, 20:1496-520.

Diethelm O. 1939. An historical review of somatic therapy in psychiatry. Am J Psychiatry, 95:1165-79.

Dostrovsky JO, Lozano AM. 2002. Mechanisms of deep brain stimulation. Mov Disord, 17(Suppl 1):S63-S68.

Eidelberg D, Moeller JR, Antonini A, et al. 1997. The metabolic anatomy of Tourette's syndrome. Neurology, 48:927-34.

Ernst M, Zametkin AJ, Jons PH, et al. 1999. High presynaptic dopaminergic activity in children with Tourette's disorder. J Am Acad Child Adolesc Psychiatry, 38:86-94.

Favre J, Taha JM, Burchiel KJ. 2002. An analysis of the respective risks of hematoma formation in 361 consecutive morphological and functional stereotactic procedures. Neurosurgery, 50:48-57.

Filali M, Hutchison WD, Palter VN, et al. 2004. Stimulation-induced inhibition of neuronal firing in human subthalamic nucleus. Exp Brain Res, 156:274-81.

Fins JJ. 2003. From psychosurgery to neuromodulation and palliation: history's lessons for the ethical conduct and regulation of neuropsychiatric research. Neurosurg Clin N Am, 14:303-19.

Flaherty AW, Williams ZM, Amirnovin R, et al. 2005. Deep brain stimulation of the anterior internal capsule for the treatment of Tourette syndrome: technical case report. Neurosurgery, ONS4:E403.

Frankel M, Cummings J, Robertson M, et al. 1986. Obsessions and compulsions in Gilles de la Tourette's syndrome. Adv Neurol 36:378-82.

Freudenberg F, Dieckmann M, Winter S, et al. 2007. Selective breeding for deficient sensorimotor gating is accompanied by increased perseveration in rats. Neuroscience, 148:612-22.

Frey KA, Albin RL. Neuroimaging of Tourette syndrome. 2006. J Child Neurol, 21:672-7.

Fukada M, Mentis MJ, Ma Y, et al. 2001. Networks mediating the clinical effects of pallidal brain stimulation for Parkinson's disease: a PET study of resting-state glucose metabolism. Brain, 124:1601-9.

Gallagher CL, Garell PC, Montgomery Jr EB. 2006. Hemi tics and deep brain stimulation. Neurology, 66:E12.

Garcia L, D'Alessandro G, Bioulac B, et al. 2005. High-frequency stimulation in Parkinson's disease: more or less? Trends Neurosci, 22:209-16.

Gilbert D. 2006. Treatment of children and adolescents with tics and tourette syndrome. J Child Neurol, 21:690-700.

Gilles de la Tourette GAEB. 1885. Etude sur une affection nerveuse caracterisee par de l'incoordination motrice accompagnee d'echolalie et de copralalie. Arch Neurol, 9:19-42.

Gorgulho A, De Salles AA, Frighetto L, et al. 2005. Incidence of hemorrhage associated with electrophysiological studies performed using macroelectrodes and microelectrodes in functional neurosurgery. J Neurosurg, 105:888-96. 
Grabli D, McCairn K, Hirsch EC, et al. 2004. Behavioural disorders induced by external globus pallidus dysfunction in primates: I. Behavioural study. Brain, 127:2039-54.

Graybiel AM, Aosaki T, Flaherty AW, et al. 1994. The basal ganglia and adaptive motor control. Science, 265:1826-31.

Haber S, Kowall N, Vonsattel J, et al. 1986. Gilles de la Tourette syndrome: a post-mortem neuropathological and immunohistochemical study. J Neurol Sci, 75:225-41.

Haber SN, Wolfer D. 1992. Basal ganglia peptidergic staining in Tourette syndrome: a follow-up study. Adv Neurol, 48:145-50.

Hadamitzky M, Harich S, Koch M, et al. 2007. Deficient pre-pulse inhibition induced by selective breeding of rats can be restored by the dopamine D2 antagonist haloperidol. Behav Brain Res, 177:364-7.

Hamani C, Lozano AM. 2006. Hardware-related complications of deep brain stimulation: a review of the published literature. Stereotact Func Neurosurg, 84:248-51.

Hamani C, Moro E. 2007. Surgery for other movement disorders: dystonia, tics. Curr Opin Neurol, 20:470-6.

Harcherik DF, Leckman JF, Detlor J, et al. 1984. A new instrument for clinical studies of Tourette's syndrome. Am J Acad Child Psychiatry, 23:153-60.

Hardesty DE, Sackeim HA. 2007. Deep brain stimulation in movement and psychiatric disorders. Biol Psychiatry, 61:831-5.

Harris K, Singer HS. 2006. Tic disorders: neural circuits, neurochemistry, and neuroimmunology. J Child Neurol, 21:678-89.

Hassler R, Dieckmann G. 1970. Traitement stéréotaxique des tics et cris inarticulés ou coprolaliques considérés comme phenomena d'obsession motrice au cours de la maladie de Gilles de la Tourette. Revue Neurologique (Paris), 123:89-100.

Houeto JL, Karachi C, Mallet L, et al. 2005. Tourette's syndrome and deep brain stimulation. J Neurol Neurosurg Psychiatry, 76:992-5.

Hyde TM, Stacey ME, Coppola R, et al. 1995. Cerebral morphometric abnormalities in Tourette's syndrome: a quantitative MRI study of monozygotic twins. Neurology, 45:1176-82.

Itard JMG. 1825. Mémoire sure quelques fonctions involontaires des appareils de la locomotion, de la préhension et de la voix. Archives Generales de Médecine, 8:385-407.

Jankovic J. 1994. Botulinum toxin in the treatment of dystonic tics. Mov Disord 9:347-9.

Jankovic J. 2001. Tourette's syndrome. N Engl J Med, 345:1184-92.

Jiménez-Jiménez FJ, García-Ruiz PJ. 2001. Pharmacological options for the treatment of Tourette's disorder. Drugs, 61:2207-20.

Kalanithi PSA, Zheng W, Kataoka Y, et al. 2005. Altered parvalbuminpositive neuron distribution in basal ganglia of individuals with Tourette syndrome. Proc Natl Acad Sci U S A, 102:13307-12.

Kopell BH, Greenberg B, Rezai AR. 2004. Deep brain stimulation for psychiatric disorders. J Clin Neurophysiol, 21:51-67.

Kopell BH, Rezai AR. 2003. Psychiatric neurosurgery: a historical perspective. Neurosurg Clin N Am, 14:181-97.

Krauss JK, Jankovic J. Severe motor tics causing cervical myelopathy in Tourette's syndrome. Mov Disord 11:563-6.

Kuhn J, Lenartz D, Mai JK, et al. 2007. Deep brain stimulation of the nucleus accumbens and the internal capsule in therapeutically refractory Tourette-syndrome. J Neurol, 254:963-5.

Kulisevsky J, Berthier ML, Avila A. 1995. Longitudinal evolution of prefrontal leucotomy in Tourette's syndrome. Movement Disorders, 10:345-8.

Kurlan R. 1997. Treatment of tics. Neurol Clin, 15:403-9.

Kurlan R, Caine E, Lichter D, et al. 1988. Surgical treatment of severe obsessive-compulsive disorder associated with Tourette's syndrome. Neurology, 38(Suppl 1):203-4.

Kurlan R, Kersun J, Ballantine Jr HT, et al. 1990. Neurosurgical treatment of severe obsessive-compulsive disorder associated with Tourette's syndrome. Mov Disord, 5:152-5.

Lavenstein BL. 2003. Treatment approaches for children with Tourette's syndrome. Curr Neurol Neurosci Rep, 3:143-8.
Leckman JF, de Lotbinière AJ, Marek K, et al. 1993. Severe disturbances in speech, swallowing, and gait following stereotactic infrathalamic lesions in Gilles de la Tourette's syndrome. Neurology, 43:890-4.

Leckman JF, Towbin KE, Ort SI, et al. 1988. Clinical assessment of tic disorder severity. In: Cohen DJ, Bruun RD, Leckman JF (eds). Tourette's Syndrome and Tic Disorders. New York: Wiley, pp. 55-78.

Leckman JF, Zhang H, Vitale A, et al. 1998. Course of tic severity in Tourette syndrome: the first two decades. Pediatrics, 102:14-9.

Leckman JF. 2002. Tourette's syndrome. Lancet, 360:577-86.

Lerner A, Bagic A, Boudreau FA, et al. 2007. Neuroimaging of neuronal circuits involved in tic generation in patients with Tourette syndrome. Neurology, 68:1979-87.

Limousin-Dowsey P, Tisch S. 2005. Surgery for movement disorders: new applications? J Neurol Neurosurg Psychiatry, 76:904.

Liu Y, Postupna N, Falkenberg J, et al. 2008. High frequency deep brain stimulation: what are the therapeutic mechanisms? Neurosci Biobehav Rev, 32:343-51.

Lozano AM, Mahat N. 2004. Deep brain stimulation surgery for Parkinson's disease: mechanisms and consequences. Parkinsonism Relat Disord, 10:S49-S57.

Lyons KE, Wilkinson SB, Overman J, et al. 2004. Surgical and hardware complications of subthalamic stimulation: a series of 160 procedures. Neurology, 63:612-6.

Maciunas RJ, Maddux BN, Riley DE, et al. 2007. Prospective randomized double-blind trial of bilateral thalamic deep brain stimulation in adults with Tourette syndrome. J Neurosurg, 107:1004-14.

Mahler M, Luke J. Outcome of the tic syndrome. J Nerv Ment Dis, 103:433-45.

McGrath MJ, Campbell KM, Parks CR, et al. 2000. Glutamatergic drugs exacerbate symptomatic behaviour in a transgenic model of comorbid Tourette's syndrome and obsessive-compulsive disorder. Brain Res, 877:23-30.

McIntyre CC, Savasta M, Walter BJ, et al. 2004. How does deep brain stimulation work? Present understanding and future questions. $J$ Clin Neurophysiol, 21:40-50.

Mink JW. 2001. Basal ganglia dysfunction in Tourette's syndrome: a new hypothesis. Pediatr Neurol, 25:190-8.

Mink JW, Walkup J, Frey KA, et al. 2006. Patient selection and assessment recommendations for deep brain stimulation in Tourette syndrome. Mov Disord, 21:1831-8.

Moldofsky H, Tullis C, Lamon R. 1974. Multiple tic syndrome (Gilles de la Tourette's syndrome). J Nerv Ment Dis, 159:282-92.

Montgomery Jr EB, Gale JT. 2008. Mechanisms of action of deep brain stimulation. Neurosci Biobehav Rev, 32:388-407.

Moriarty J, Varma AR, Stevens J, et al. 1997. A volumetric MRI study of Gilles de la Tourette's syndrome. Neurology, 49:410-5.

Müller-Vahl KR. 2002. The treatment of Tourette's syndrome: current opinions. Expert Opin Pharmacother, 3:899-914.

Nádvorník P, Šramka M, LisýL, et al. 1972. Experiences with dentatotomy. Confin neurol, 34:320-4.

Neimat JS, Patil PG, Lozano AM. 2006. Noval surgical therapies for Tourette syndrome. J Child Neurol, 21:715-8.

Nordstrom EJ, Burton FH. 2002. A transgenic model of comorbid Tourette's syndrome and obsessive-compulsive disorder circuitry. Mol Psychiatry, 7:617-25, 524.

Nuttin B, Gybels J. 2003. Deep brain stimulation for psychiatric disorders. Neurosurg Clin N Am, 14:xv-xvi.

Oh MY, Abosch A, Kim SH, et al. 2002. Long-term hardware-related complications of deep brain stimulation. Neurosurgery, 50:1268-76.

Okun MS, Fernandez HH, Foote KD, et al. 2008. Avoiding deep brain stimulation failures in Tourette syndrome. J Neurol Neurosurg Psychiatry, 79:111-2.

Okun MS, Tagliati M, Pourfar M, et al. 2005. Management of referred deep brain stimulation failures. Arch Neurol, 62:1250-5.

Pehek EA, Nocjar C, Roth BL, et al. 2006. Evidence for preferential involvement of 5-HT2A serotonin receptors in stress-and drug-induced dopamine release in the rat medial prefrontal cortex. Neuropsychopharmacology, 31:265-77. 
Peterson B, Riddle MA, Cohen DJ, et al. 1993. Reduced basal ganglia volumes in Tourette's syndrome using three-dimensional reconstruction techniques from magnetic resonance images. Neurology, 43:941-9.

Peterson BS. 2001. Neuroimaging studies of Tourette syndrome: a decade of progress. In: Cohen DJ, Jankovic J, Goetz CG (eds). Tourette syndrome. Volume 85 of Advances in neurology. Philadelphia: Lippincott Williams and Wilkins, pp. 179-96.

Robertson M, Doran M, Trimble M, et al. 1990. The treatment of Gilles de la Tourette syndrome by limbic leucotomy. J Neurol Neurosurg Psychiatry, 53:691-4.

Robertson MM, Stern JS. 2000. Gilles de la Tourette syndrome: symptomatic treatment based on evidence. Eur Child Adolesc Psychiatry, 9:I/60-I/75.

Robertson MM, Trimble MR, Lees AJ. 1989. Self-injurious behaviour and the Gilles de la Tourette syndrome: a clinical study and review of the literature. Psychol Med, 19:611-25.

Robertson MM. 2000. Tourette syndrome, associated conditions and the complexities of treatment. Brain, 123:425-62.

Sachdev P, Sachdev J. 1997. Sixty years of psychosurgery: its present status and its future. $J$ Aust $N Z J$ Psychiatry, 31:457-64.

Sakas DE, Kouyialis AT, Boviatsis EJ, et al. 2007. Technical aspects and considerations of deep brain stimulation surgery for movement disorders. Acta Neurochir Suppl, 97:163-70.

Sansur CA, Frysinger RC, Pouratian N, et al. 2007. Incidence of symptomatic hemorrhage after stereotactic electrode placement. J Neurosurg, 107:998-1003.

Sawle GV, Lees AJ, Hymas NF, et al. 1993. The metabolic effects of limbic leucotomy in Gilles de la Tourette syndrome. J Neurol Neurosurg Psychiatry, 56:1016-9.

Serra-Mestres J, Ring HA, Costa DA, et al. 2004. Dopamine transporter binding in Gilles de la Tourette syndrome: A [123I]FP-CIT/SPECT study. Acta Psychiatr Scand, 109:140-6.

Sershen H, Hashim A, Lajtha A. 2000. Serotonin-mediated striatal dopamine release involves the dopamine uptake site and the serotonin receptor. Brain Res Bull, 53:353-7.

Servello D, Porta M, Sassi M, et al. 2008. Deep brain stimulation in 18 patients with severe Gilles de la Tourette syndrome refractory to treatment: the surgery and stimulation. J Neurol Neurosurg Psychiatry, 79:136-42.

Shahed J, Poysky J, Kenney C, et al. 2007. GPi deep brain stimulation for Tourette syndrome improves tics and psychiatric comorbidities. Neurology, 68:159-60.

Shapiro AK, Shapiro ES, Young JG, et al. 1988. Signs, symptoms, and clinical course. In: Shapiro AK, Shapiro ES, Young JG, et al. (eds). Gilles de la Tourette Syndrome. 2nd edition. New York: Raven Press, pp. 127-93.

Sillay KA, Larson PS, Starr PA. 2008. Deep brain stimulator hardware-related infections: incidence and management in a large series. Neurosurgery, 62:360-6.

Singer HS, Butler IJ, Tune LE, et al. 1982. Dopaminergic dysfunction in Tourette syndrome. Ann Neurol, 12:361-6.

Singer HS, Reiss AL, Brown JE, et al. 1993. Volumetric MRI changes in basal ganglia of children with Tourette syndrome. Neurology, 43:950-6.

Singer HS, Szymanski S, Giuliano J, et al. 2002. Elevated intrasynaptic dopamine release in Tourette's syndrome measured by PET. Am $J$ Psychiatry, 159:1329-36.

Singer HS. 2001. The treatment of tics. Curr Neurol Neurosci Rep, $1: 195-202$.
Snyder SH, Taylor KM, Coyle JT, et al. 1970. The role of brain dopamine in behavioural regulation and the actions of psychotropic drugs. Am J Psychiatry, 127:199-207.

Stern E, Silbersweig DA, Chee K-Y, et al. 2000. A functional neuroanatomy of tics in tourette syndrome. Arch Gen Psychiatry, 57:741-8.

Stevens H. 1964. The syndrome of Gilles de la Tourette and its treatment. Med Ann Dist Columbia, 33:277-9, 304.

Stoetter B, Braun AR, Randolph C, et al. 1992. Functional neuroanatomy of Tourette syndrome. Limbic-motor interactions studied with FDG PET. Adv Neurol, 58:213-26.

Sun B, Krahl SE, Zhan S, et al. 2005. Improved capsulotomy for refractory Tourette's syndrome. Stereotact Func Neurosurg, 83:55-6.

Swerdlow NR, Geyer MA, Braff DL. 2001. Neural circuit regulation of prepulse inhibition of startle in the rat: current knowledge and future challenges. Psychopharmacology, 156:194-215.

Swerdlow NR, Sutherland AN. 2005. Using animal models to develop therapeutics for Tourette Syndrome. Pharmacol Ther, 108:281-93.

Swerdlow NR, Sutherland AN. 2006. Preclinical models relevant to Tourette syndrome. Adv Neurol, 99:69-88.

Swerdlow NR, Young AB. 2001. Neuropathology in Tourette syndrome: an update. In: Cohen DJ, Jankovic J, Goetz CG (eds). Tourette syndrome, Volume 85 of Advances in neurology. Philadelphia: Lippincott Williams and Wilkins, pp. 179-96.

Temel Y, Ackermans L, Celik H, et al. 2004. Management of hardware infections following deep brain stimulation. Acta Neurochir (Wien), 146:355-61.

Temel Y, Visser-Vandewalle V. 2004. Surgery in Tourette syndrome. Mov Disord, 19:3-14.

The Tourette Syndrome Classification Study Group. 1993. Definitions and classifications of tic disorders. Arch Neurol 50:1013-6.

van der Linden C, Colle H, Vandewalle V, et al. 2002. Successful treatment of tics with bilateral internal pallidum (GPi) stimulation in a 27 -year-old male patient with Gille de la Tourette's syndrome (GTS). Mov Disord, 17(Suppl 5):S341

Visser-Vandewalle V, Ackermans L, van der Linden C, et al. 2006. Deep brain stimulation in Gilles de la Tourette's syndrome. Neurosurgery, 58:E590.

Visser-Vandewalle V, Temel Y, Boon P, et al. 2003. Chronic bilateral thalamic stimulation: a new therapeutic approach in intractable Tourette syndrome. J Neurosurg, 99:1094-100.

Visser-Vandewalle V, van der Linden C, Groenewegen HJ, et al. 1999. Stereotactic treatment of Gilles de la Tourette syndrome by high frequency stimulation of thalamus. Lancet, 353:724.

Visser-Vandewalle V. 2007. DBS in Tourette syndrome: rationale, current status and future prospects. Acta Neurochir Suppl, 97:215-22.

Whitty CWM, Duffield JE, Tow PM, et al. 1952. Anterior cingulectomy in the treatment of mental disease. Lancet, 1:475-81.

Wolf SS, Jones DW, Knable MB, et al. 1996. Tourette syndrome: prediction of phenotypic variation in monozygotic twins by caudate nucleus D2 receptor binding. Science, 273:1225-7.

Wong DF, Pearlson GD, Young LT, et al. 1989. D2 dopamine receptors are elevated in neuropsychiatric disorders other than schizophrenia. J Cereb Blood Flow Metab, 9(Suppl 1):S593.

Wong DF, Singer HS, Brandt J, et al. 1997. D2-like dopamine receptor density in Tourette syndrome measured by PET. J Nucl Med, 38:1243-7.

Zimmerman AM, Abrams MT, Giuliano JD, et al. 2000. Subcortical volumes in girls with Tourette syndrome. Neurology, 54:2224-9. 